\title{
TRINITARIANISM IN DIDACHE, BARNABAS, AND THE SHEPHERD: SKETCHY, SCANT, OR SCANDALOUS?
}

\author{
MichaEL J. SVIGEL* \\ Dallas Theological Seminary
}

\begin{abstract}
A survey of works on the development of nascent trinitarianism, especially in the last several decades, reveals that most treatments cut a wide path around three of the earliest Christian writings: Didache, Barnabas, and Shepherd of Hermas. Because these writings straddle the apostolic/post-apostolic eras (c. AD 50-150), they should be regarded as essential links in any historical account of the development of trinitarian theology. Nevertheless, these writings have sometimes been regarded as having sketchy, scant, or scandalous christologies and pneumatologies. This article argues that the typical critical estimations of these writings as nontrinitarian are under-supported by the textual evidence. Rather, Didache, Barnabas, and the Shepherd of Hermas may very well presuppose a basic christocentric and trinitarian creationredemption narrative. Far from scandalous, these texts provide a positive link in the continuity from seminal apostolic trinitarian thought to the later trinitarian growth of the second century.
\end{abstract}

KEYWORDS: Trinitarianism, christology, Didache, Barnabas, Shepherd of Hermas

\section{Introduction}

A survey of works on trinitarianism in the last century-and especially in the last few decades-reveals that a large number virtually ignore the first century after the apostolic age as they attempt to reconstruct the development of trinitarian thought (Butin 2001: 45-52; LaCugna 1991: 24-30; O'Collins, 1999: 85-103). Some have begun their histories of trinitarianism in the later second century with such writers as Justin Martyr (Paine 1900: 24), Irenaeus (Coppedge 2007: 89; de Margerie 1975: 91-172; Gunton 1998: xxi, 47-50), or Tertullian (Anatolios 2011: 16). Others have started in the third century with Origen's controversial treatments of the Logos (Hodgson 1944: 142-175; Pittenger 1977: 39-43). Still others have skipped the first two centuries altogether, beginning their discussions with Athanasius or the Cappadocians (Clark 1990:17-28; Fatula 1990: 62-64; Giles 2002: 32). One author began his history of trinitarianism with Augustine, for which he actually apologized (Mascall 1986: 8, 11). Some scholars have at

* MICHAEL J. SVIGEL (PhD 2008, Dallas Theological Seminary) is Chair and Professor of Theological Studies at Dallas Theological Seminary. Email: msvigel@dts.edu. 
least attempted to take the contributions of the first two centuries seriously, but they have often resorted to vague reports or unhelpful summaries (Beisner 1984: 46-49; Moltmann 1993: 130; Pannenberg 1991: 268-271).

A few scholars, however, have attended to the writings of the earliest fathers in some detail with helpful and sometimes thorough treatments of the most relevant trinitarian, christological, or pneumatological passages (Grant 1990: 58; Fortman 1972: 37-44; Olson and Hall 2002: 16). Yet even generous treatments of the early history often steer a wide path around three of the earliest—and admittedly most irksome-Christian writings: the very early Didache, the so-called Epistle of Barnabas, and the Shepherd of Hermas (cf. Fairbairn 2009; Holmes 2012; Letham 2004; Marmion and van Nieuwenhove 2011). These three writings-at least as a group, if not individually-straddle the apostolic and post-apostolic ages (c. AD 50-150). Though they should be expected to function as essential links in a historical account of the development of trinitarian theology, at times Didache, Barnabas, and the Shepherd have been regarded by some as having sketchy, scant, or even scandalous christologies and pneumatologies.

Such negative evaluations of the trinitarian content of these works, however, are not above critique. In this article, I will argue that the typical critical estimations of these writings as non-trinitarian are under-supported by the textual evidence. I will further suggest that Didache, Barnabas, and the Shepherd of Hermas may very well presuppose a basic christocentric trinitarian creation-redemption narrative. Far from scandalous, these texts provide a positive link in the continuity from seminal apostolic trinitarian thought to the later trinitarian growth of the second century.

\section{In the Name of the Lord: The 'Sketchy' Trinitarianism of Didache}

Contrasted with the high incarnational christology of Ignatius' writings (see Svigel 2016: 47-174), it is often asserted that the Didache has a low christology—or at least that the Didache represents an earlier stage of Christian development when the communities were primarily concerned with Jesus' teachings (logia) rather than teachings about Jesus (Draper 1996: 72-91). In keeping with this notion, Grant includes the Didache as one of many examples of Jewish Christian writings that do not call Jesus 'God'-an argumentum ex silentio, but an allegedly silentia magna (Grant 1967: 13). However, to rely on this silence as an indication that the didachist's original community held to a low christology is to go beyond the evidence. Given the main concerns in the Didache as a catechetical work or church-order (Wengst 1984: 18), the Didache cannot be expected to represent a community's entire theology (Kraft 1965: 65; Niederwimmer 1998: 2).

Despite limitations due to Didache's narrow scope and purpose, some basic contours of the didachist's theology—and perhaps even an imbedded 
trinitarianism-can still be discerned. Naturally, we must begin with the famous triadic baptismal pronouncement in Didache 7, which suggests some relationship of at least functional harmony between Father, Son, and Holy Spirit (cf. Matthew 28:19; 2 Corinthians 13:14; 1 Peter 1:2). However, even here we find ourselves treading choppy waters, as the estimation of this evidence of nascent trinitarian thought has been challenged. So Géza Vermes argues that as a result of the 'slow progress of Trinitarian theology in the early church', baptism in the triune name is likely not part of the original text, but a later interpolation-a conclusion apparently supported by the fact that baptism is later described as being administered not in the name of the Father, Son, and Spirit, but 'in the name of the Lord' in Didache 9.4 (Vermes 2014: 139-140).

This estimation of the value of Didache's triadic baptismal formula, however, must be significantly tempered, if not gently censured. Besides assuming that which is to be proved ('the slow progress of Trinitarian theology in the early church'), it represents what I believe to be a shallow reading of the passage in context. Even if the triadic formula refers to a later layer of Didache's redaction history, it still likely represents a first-century tradition, as does the Gospel of Matthew's triune baptism. This means baptism in the name of the Father, Son, and Holy Spirit was at least part of the tradition represented by the Didache during the transition from the first to second generation of Christians. Also, we should not neglect the fact that the triadic baptism had also made an impact on the actual practice of the rite, as the person performing an alternative to immersion was to pour water three times in the name of the Father, Son, and Holy Spirit. While words of a formula can easily be interpolated, actual practices in a ritual are stubborn things.

But what are we to make of the apparent contradiction between the triadic baptism in Didache 7.1, 3 and the allegedly monadic formula of in the name of the Lord' in 9.5 (Draper 2007: 17)? If we suspend the presupposition of non-trinitarianism in the earliest layers of redaction, it could just as plausibly be argued that 'name of the Lord' is a short equivalent to 'name of the Father, Son, and Holy Spirit'. In fact, already the second iteration of the baptismal formula in Didache 7.3 shortens the longer Matthean phrase of 7.1:

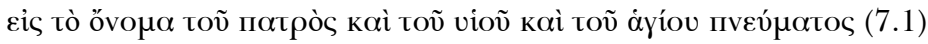

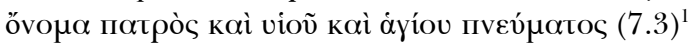

1 All citations of the Greek text of The Apostolic Fathers in this article are from Holmes (2007). All English translations of original texts are my own. 
It is not unreasonable to argue that the shortened form in 9.5 (zis övopa kupíov) is simply a further abbreviation of what was a normal triadic baptismal formula at the time. In this case, the name kúpıos could be a reference to the one true God (יהוה), not to the Lord Jesus in particular. This possibility is further strengthened when one considers that the phrase tò

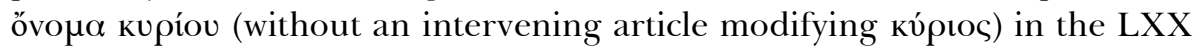
and in most New Testament passages, is a reference to יהוה. In most cases when the phrase 'the name of the Lord' refers to Jesus, kv́pıos takes the

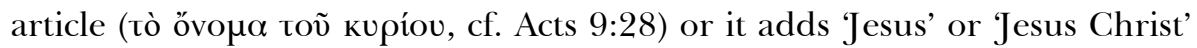

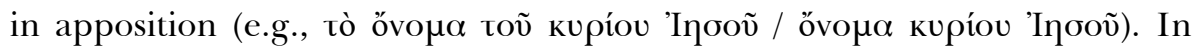
fact, the phrase 'baptized in the name of the Lord' does not appear in the New Testament apart from the name 'Jesus' (see Acts 2:38; 8:12, 16; 10:48;

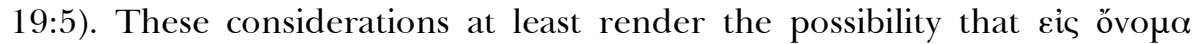
kupíou in Didache 9.5 is not an earlier or competing non-triadic formula but actually an indication of a nascent trinitarianism; the triad, 'Father, Son, and Holy Spirit' in Didache 7.3 in this case would be equated with the divine name- kv́pısos (יהוה)—in Didache 9.5.

However, Didache does not develop the theological significance of the triadic baptismal formula, and the remainder of Didache is admittedly rather sketchy regarding the interpersonal relationships of the Father, Son, and Spirit. Yet Didache does indicate that in the prayer following the eucharist, the church was to pronounce, 'Maranatha' (see 1 Corinthians 16:22; Revelation 22:20), an Aramaic term that refers to Jesus as 'Lord' in at least an exalted sense, if not ascribing divinity to Christ (Cullmann 1963: 199-214; Longenecker 1970: 121-124). Nevertheless, direct ascriptions of deity to Christ are lacking in the Didache. Even assuming $\theta \varepsilon \tilde{\varphi}$ to be original in Didache 10.6 (but see variant readings), there is no reason to conclude that 'God of David' refers to Christ rather than to the Father, as it does in Psalm 118:25 (Witherington 1998: 229). It is certain, however, that without an $a$ priori assumption of a 'slow progress of Trinitarian theology in the early church' (Vermes 2014: 139) one cannot confidently conclude that the didachist or his community held to a low christology and a non-trinitarian theology.

Descriptions of Christ's role of submission to God also factor into one's understanding of the christology (and thus, trinitarianism) of the didachist, though whether such statements evince a low christology is unclear. So, for example, we find in the various prayers prescribed for eucharistic worship a repetition of Jesus as God's servant, паĩs (Did. 9.2, 3; 10.2, 3; cf. 1 Clem. 59.2, 3, 4; Acts 4:27; Isaiah 41:8-9; 42:1; 44:1-2; 49:6; 52:13). Granted, it can be argued that the use of поī here reveals a low 'Davidic' or 'Agent' christology—one that regards Christ as merely a human agent through whom God accomplishes his divine plan. However, without any explicit 
statements that establish that the didachist or his community actually denied the deity of Christ, a reading that associates Davidic or servant christology with a low christology (and thus a non-trinitarian theology) goes beyond the evidence. In fact, other early Christian writings that exhibit high christologies also affirm the title 'servant' (паī) of God. Consider, for example, Martyrdom of Polycarp 14.3: 'I praise you, I bless you, I glorify you, through the eternal and heavenly high priest Jesus Christ, your beloved servant (паі)), through whom to you with him and the Holy Spirit be glory both now and unto the coming ages' (cf. Martyrdom of Polycarp 14.1; Hildebrand 2011: 95; Hartog 2014: 40-44). Likewise, the Letter to Diognetus maintains both a high christology (Diogn. 7.4) and the title пог̃ (8.9, 11;9.1), indicating that паĩs is a perfectly appropriate title for Christ within the context of a high incarnational christology.

Except for prominent inclusion with the Father and Son in the baptismal formula of chapter 7, the pneumatology of the Didache is not well developed. The didachist does say the Holy Spirit prepares those whom God will later call (Did. 4.10; cf. Barn. 19.7). In the Apostolic Fathers, the action of

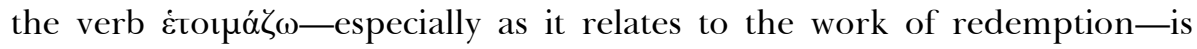
predominantly attributed to God (1 Clem. 34.8; 35.3; 39.9; 2 Clem. 14.5; Ign. Rom. 5.2; Barn. 3.6; 14.6; Diogn. 8.11). In Didache itself, God is the one who has prepared the kingdom for his church (Did. 10.5). A similar thought in 1 Clement 22.1 and the exact parallel line from the Two Ways section of Barnabas 19.7 both strengthen this position that the Spirit of Didache 4.10 is thought of as divine. And in the prayer of Didache 10.2, all three persons of the Trinity are involved in the work of redemption.

To sum up, with regard to the trinitarianism of the Didache, scholars tend either to read the text in light of a presupposed non-trinitarian theology, or they fail to produce sufficient evidence to demonstrate that the Didache precludes trinitarian thought. At the same time, several lines of evidence and arguments strengthen the plausibility that the didachist and his community were, in fact, representatives of nascent trinitarianism. Though the Didache ought to be regarded as sketchy in its presentation of the Father, Son, and Holy Spirit, it should not be regarded as incompatible with later trinitarian refinement and expression.

\section{From the Riches of the Lord's Fountain: The 'Scant' Trinitarianism of Barnabas}

While the provenance of the anonymous Epistle of Barnabas is uncertain (Barnard 1958: 212; 1993: 172-180; Loman 2005; Paget 1994: 3-7; Prigent 1961: 113-118), many date the composition of the work sometime between about AD 80 and 140 (Jefford 2006: 34; Prostmeier 1999: 111-119). Thus, 
Barnabas provides an important portal into the development of early trinitarianism in the transition from the first to second centuries.

Because Barnabas has nothing like the trinitarian formula of Didache 7, the starting point for exploring nascent trinitarian thought in Barnabas must begin with the christological and pneumatological components of the trinitarian hypothesis. With regard to christology, the author made it clear that the Son was equally involved with the Father in creation. The Son is 'Lord of the whole world' (œ̂v паvтòs toṽ kóopov kv́pıos); and it was to him that God spoke when he said, 'Let us make humanity according to our image and likeness' (Barn. 5.5-6). Here we have not only a firm assertion of the incarnation of a pre-incarnate Son (cf. 6.12) but also an affirmation of Christ's deity (Hanson 1989: 156; Prostmeier 1999: 244). The title 'Son of God' in Barnabas refers to his divinity $(5.9-13,11 ; 7.2 ; 13.10)$, and although he is 'Lord of all', Christ submitted to suffering voluntarily, not under compulsion, as an act of grace ( $5.5 ; 7.1-2)$.

In Barnabas 12, the author conscripted Old Testament passages to serve his high christology, including Moses lifting his hands to conquer the enemies of Israel as well as raising the serpent in the wilderness (12.1-7). The author summarized, 'You have again in these things the glory of Jesus, be-

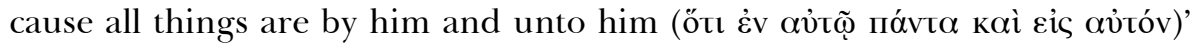
(12.7). The concluding ötı clause reveals an important theological presupposition of the author that affects his hermeneutic: references to Jesus and the cross were to be found throughout scripture because all thingsincluding Old Testament narratives-pointed to him. It should not be surprising, then, that the author casually cites a more conventional messianic text in Psalm 110:1 (109:1 in the LXX), noting, 'Behold how David calls him "Lord", and does not say "son" (12.11). All of this reveals an underlying assumption of a high christology—a foundational presupposition of trinitarianism.

When referring to the Old Testament narrative of Joshua (Jesus) son of Nun, the author concluded, 'Behold again Jesus—not son of man but son of God, and revealed in the flesh by a type' (Barn. 12.10). This kind of christocentric typological interpretation is in keeping with the author's general approach to Old Testament scripture, which also fits with a common approach to biblical interpretation during this period (Longenecker 1999; O'Hagen 1963: 33-40). Through this typology, Barnabas presents a preincarnate Son similar to that found in Paul, Hebrews, and the Fourth Gospel. In other words, the author's high christology dominates his reading of the text.

Not only is the Son at work with the Father as mediator in the preparation of those who are to believe (Barn. 3.6), but so is the Holy Spirit (19.7; cf. Did. 4.10). This functional parallel between the work of Christ and the 
work of the Spirit suggests at least the beginnings of an awareness of economic intra-trinitarian relationships. Nowhere, though, does the author ask or answer the question concerning the Spirit's nature and origin. Even the figurative reference to the Spirit being "poured out... from the abundance

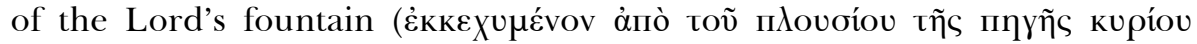

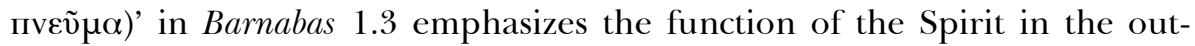
working of God's plan of redemption, not speculation regarding the Spirit's ontological relationship with the Father (cf. 1 Clem. 2.2).

In another pneumatologically significant passage, Barnabas 14.2 (cf. 4.7), we read, 'And Moses received from the Lord the two tablets which were in-

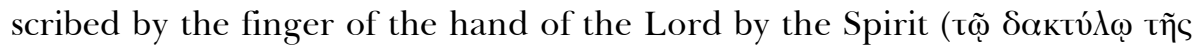

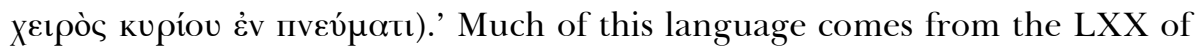

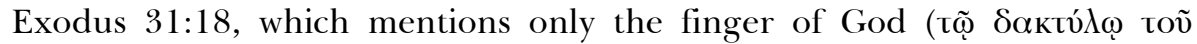
$\theta \varepsilon$ oṽ). The parallel in Deuteronomy 9:10 includes an instrumental use of $\dot{\varepsilon} \mathrm{v}$

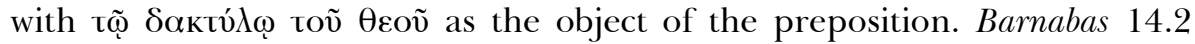
seems to parallel Deuteronomy's instrumental use of $\dot{\varepsilon}$, but with a single

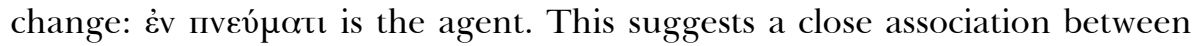
the 'finger of God' and 'the Spirit' in the mind of the author of Barnabas (cf.

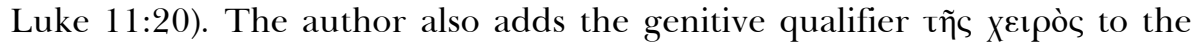
normal biblical phrase; thus the law was inscribed 'by the finger of the hand of the Lord by the Spirit'.

The string of prepositional phrases may be awkward, but it is laden with theological possibilities. In several passages in the Septuagint, the image of God's 'hand' is used to refer to his mighty works of deliverance (e.g., Deuteronomy 4:34; Jeremiah 32:21). The phrase $\chi$ عì kupíou is even used in the Septuagint with reference to the revelatory 'word of the Lord' ( $\lambda$ óyos kupíou): 'The word of the Lord came to Ezekiel...and the hand of the Lord came upon me' (Ezekiel 1:3). This 'hand of the Lord' functions as the direct agent of God's self-revelation, speaking to, transporting, and enabling the prophet to prophesy (Ezekiel $3: 14,22 ; 8: 1 ; 33: 22 ; 40: 1$ ). And in Ezekiel 37:1, the hand of the Lord is even associated with the Spirit's activity: And the hand of the Lord came upon me, and it brought me out by the spirit of

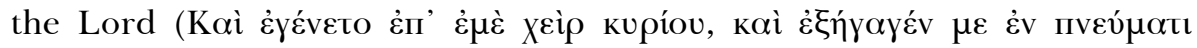
kúptos).' Therefore, it may be that the author of Barnabas was intentionally associating all three persons of the Trinity with involvement in the inscription of the Law-the 'hand of the Lord' was meant as a reference to the Son while the 'finger' referred to the Spirit-imagery similar to that developed later in Irenaeus (Haer. 3.21.10; 4. pref. 4; 4.20.1; 5.5.2; 5.6.1; 5.15.2; Demonstr. 26).

To conclude, the Epistle of Barnabas has a markedly high christology, though the specific nature of the Son's relationship to the Father and Spirit is not precisely defined. Nevertheless, the pre-incarnate existence of the 
Son is expressed in no uncertain terms. Clear assertions of the Spirit's distinct personhood and deity are not found in Barnabas, though nothing in the text clearly opposes the basic contours of trinitarian thought. Barnabas could therefore be understood as not being inconsistent with later trinitarian reflection and articulation, but as scant with regard to the quantity of clear contributions to trinitarian thought and development. In other words, the author of Barnabas may very well have held to a more developed trinitarian theology than his epistle reveals (cf. Fortman 1972: 42-43), but we are left with only hints and suggestions of such trinitarianism. Claiming that Barnabas is non-trinitarian, however, goes beyond the evidence.

\section{Master, Slave, and Son: The 'Scandalous' Trinitarianism of Shepherd of Hermas}

Though highly valued in the early church as an inspiring - if not inspiredwork (e.g., Origen On First Principles 1.3.3; 2.1.5; Athanasius On the Incarnation 3), the Shepherd of Hermas has long challenged scholars with regard to issues of date, authorship, and integrity (Brox 1991: 29-33; Kirkland 1992: 87-102; Osiek 1999: 18-20). The introductory issues are complicated, but I believe some redactional development of the Shepherd occurred between the years $\mathrm{AD} 80$ and 140, perhaps partially by the hand of the same author, 'Hermas', who edited his own work throughout his life (Svigel 2016: 250251; cf. Jeffers 1990: 14; Joly 1993: 527-529; Wilson 1995: 9-37). In any case, scholars generally agree that the Shepherd arrived at its final form by the middle of the second century (Verheyden 2007: 64-65). It thus serves as an important witness to the status of nascent trinitarianism in the late first to early second centuries.

As we see in both the New Testament and other first- and secondcentury Christian literature, in the Shepherd the Father operates in the economy of creation through the personal mediation of his Son. While God sent commandments through his Son (Herm. Sim. 5.5.3), the Son's power and authority are consistently presented as coming from the Father (5.6.4), and it was God who gave the Son those who are part of his new creation (5.6.3). In the direction of humanity toward God, Christians are called through the Son (8.11.1), believe in God through the Son (9.13.5), and enter the Kingdom by means of his Son $(9.12 .3 ; 9.12 .4-6)$. In fact, even angels cannot enter the presence of God without the Son (9.12.8).

In many places the christology of the Shepherd appears to be quite high. This is particularly the case in Vision 2.2.8, where the Father is said to have

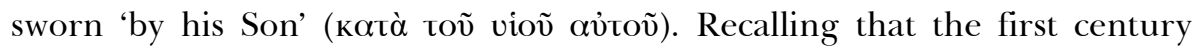
book of Hebrews says that God confirms vows by himself ( $\left.k \alpha \theta^{\prime} \dot{\varepsilon} \alpha u t o \tilde{u}\right)$ 'since He could vow by no one greater' (Hebrews 6:13), could the author of the Shepherd have had this principle in mind when he said the Father swore 
'by his Son'? If the author of 1 Clement knew the book of Hebrews (see 1 Clem. 17.1; 36.2-5; 43.1; 56.4), it is quite plausible that Hermas-likewise writing from Rome in the same generation-also knew Hebrews (cf. the likely allusion to Hebrews 6:6 in Herm. Mand. 4.3.1). Thus, Hermas may have been intentionally drawing on the principle of God swearing by himself in Hebrews 6:13, rendering a subtle but powerful allusion to a very high christology (Dibelius 1923: 448; Osiek 1999: 56).

It comes as no surprise, then, that the 'Son of God' is clearly presented as pre-existing. Similitude 9.12.2 states, 'The Son of God is prior in existence

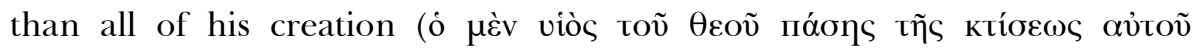

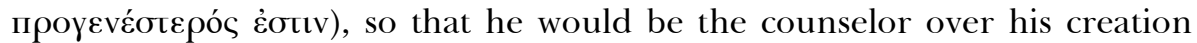
with the Father.' However, Osiek (1999: 233) notes: 'But he is in good company: previously the church and the great angel are also said to be preexistent (Herm. Vis. 2.4.1 and 3.4.1).' On the other hand, the Son's involvement as the personal agent of creation-a distinctly divine function in the Shepherd (Herm. Mand. 1.1)—still indicates a very high christology. This is reinforced by several passages in which the Son functions in a role of cooperation with-though submission to-the Father's will (Herm. Sim. 5.6.7; 9.12.2).

Moving from christology to pneumatology, the appellation 'Spirit of God' (Herm. Mand. 10.2.6) certainly indicates some kind of relationship with divinity - a notion spelled out explicitly in Mandate 11.17, though this origination elsewhere refers to the Son's function in the economy of creation (11.21). Perhaps the most pronounced attribution of the Spirit's deity, though, appears in the portrayal of the Spirit as directly creating the universe in Similitude 5.6.4: 'The preexisting Holy Spirit, who created the

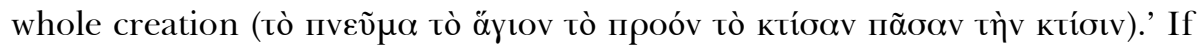
this is a reference to the Spirit and not to the pre-incarnate Son (see discussion below), then we have in the Shepherd both the Son and the Spirit directly involved in creation (Herm. Sim. 9.12.2).

Though we have thus far seen the raw materials of a primitive trinitarian theology, the Shepherd also contains several passages that suggest to many readers a confused christology and pneumatology, thus resulting in an allegedly problematic trinitarianism (see Fortman 1972: 40-41). Particularly troublesome is the presentation of Christ in Parables 5 and 9. Grant (1964: 131) speaks for a host of commentators who regard Similitude 5 as the author's sub-orthodox understanding of the incarnation and resultant trinitarian confusion: 'The incarnation is described thus (Herm. Sim. 5, 6): God made the Holy Spirit dwell in the flesh which he chose, and this flesh served

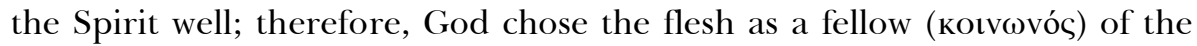
Spirit and gave it a place of tabernacling.' Many others have read this passage as indicating a non-trinitarian theology (cf. Dibelius 1923: 574; Osiek 
1999: 181). Stewart-Sykes refers to the christology of Hermas as a 'SpiritChristology' in which the Spirit of God dwelled in the flesh of Christ (Stewart-Sykes 1997: 273; cf. Harnack 1905: 191). Papandrea (2016: 29) suggests that the Shepherd presents a confused 'Angel Adoptionism'. And Vermes calls Hermas' teaching 'the incarnation of the Holy Spirit' (2014: 174). Certainly, if Similitude 5 is actually presenting a kind of dynamic monarchianism, a Spirit-christology, or an angel-christology, this would result in a problematic mutation in the development of orthodox trinitarianism.

However, elsewhere I have made a case for an interpretation of Similitude 5 that places it in its broader structural context, emphasizes its paraenetic purpose, and demonstrates that the Son and Holy Spirit are not, after all, confused in a kind of sub-trinitarianism (Svigel 2016: 253-261). Structurally, Similitude 5 presents two interpretations and a final application (cf. Henne 1988: 573; Henne, 1992a: 160; Stewart-Sykes, 1997: 278-280; Osiek, 1999: 168). The first interpretation (Herm. Sim. 5.3) addresses Hermas' very practical matter of fasting. The second interpretation (5.5-6) presents a deeper christological exposition of the details of the parable. Both of these (the practical and the christological) come together to present Christ as the perfect image or example in the final application of both interpretations (5.7).

A case can therefore be made for reading the parable as referring not to the adoption of a merely human 'son' by the divine Spirit, but as the coming of the divine Spirit to indwell and empower the incarnate Son of God for the work of his earthly prophetic ministry (cf. Hauck 1993: 187-198). Given the great number of biblical texts referring to the anointing and empowering work of the Spirit in the life of the Messiah, there is good reason to expect the author of the Shepherd to present the functional relationship between the Son and the Spirit during Christ's earthly ministry in a similar fashion (see Isaiah 61:1-3; Matthew 3:16 [=Mark 1:10-11; Luke 3:22; John 1:32]; Matthew 4:1 [=Luke 4:1]; Matthew 12:18, 28; Luke 4:14, 18; 10:21; 18:18-21; John 1:32-33). Only if a reader presupposes a very slow evolution of trinitarianism and thus insists on interpreting the parable in light of a pre-orthodox christology do contradictions like this arise: 'In contrast to the adoptionistic Christology of Sim. V, Sim. IX displays a pre-existent Christology similar to that of the Fourth Gospel' (Wilson 1995: 76). We must recognize that the kind of dynamic relationship between Christ and the Spirit in the fifth parable is actually consistent with the roles of the Son and Spirit portrayed in the canonical Gospels. The Spirit's work in the life and ministry of the incarnate Son of God does not stand in contrast to a high christology.

This interpretation is confirmed by the fact that the purpose of presenting the parabolic narrative was not to advance the author's christology per se, but to establish Christ as a model for all Christians indwelled by the Spir- 
it. We must remember that Similitude 5 is not an excursus on christology and pneumatology, but a homily on Christ's example for all Spirit-indwelled Christians. The author's paraenetic purpose was to prompt his readers to imitate Christ. Thus, the parable is not primarily christocentric or christotelic, but 'christiconic' (see Kuruvilla 2013: 259-262). If we see the empowerment of the Spirit in the life of Christ as an exemplar that all believers can emulate, the apparent christological problems in the passage are to a large extent resolved. Christians were to follow Christ's example of cooperating with the indwelling Spirit, thereby attaining to the resurrection of the dead and the adoption as sons (cf. Romans 8:15, 23; Galatians 4:5; Ephesians 1:5). Of course, many orthodox readers would still wish that the phrase 'the

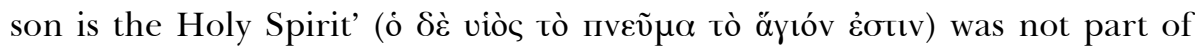
this interpretation of the parable, even though a close reading reveals that Jesus Christ is not, in fact, equated with the Holy Spirit in a personal sense (Henne 1992a: 189, 90; Svigel 2016: 253-261; 2 Corinthians 3:16-18).

This already troublesome parable also presents Christ as a 'slave'. On the surface, this too might offend those who hold to a high christology. In fact, even Hermas himself was surprised: 'Why, sir,' Hermas asks, 'is the Son of God set forth in the parable in the manner of a slave?' (Herm. Sim. 5.5.5). The Shepherd responds that Hermas had misunderstood the significance of the symbolism: 'Listen, the Son of God is not set forth in the manner of a

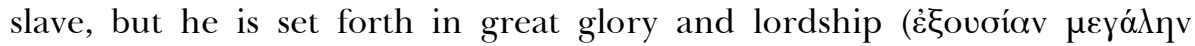

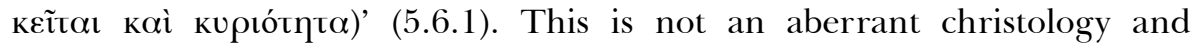
pneumatology; these descriptions are actually consistent with the roles of the Son and Spirit in the earthly ministry of Christ presented in the canonical Gospels themselves (Matthew 3:16 [=Mark 1:10; Luke 3:22; John 1:32]; Matthew 4:1 [=Luke 4:1]; Matthew 12:18, 28; Luke 4:14, 18; 10:21).

Its initial unexpected language and perplexing imagery aside, there is nothing in Similitude 5 that fundamentally conflicts with a later orthodox explication of incarnational christology or even developed trinitarianism. The key to understanding the christology, pneumatology, and thus trinitarian theology of Similitude 5 is in realizing that the author was using the functions of the Father, Son, and Spirit in the earthly ministry of Christ to make a practical application to the Christian life. He writes, 'For all flesh (по̃ $\alpha \alpha$ yò $\sigma \alpha \grave{\rho} \xi)$ found undefiled and without spot, in which the Holy Spirit

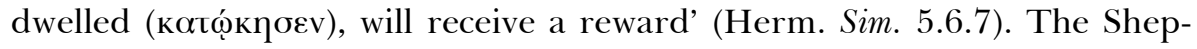
herd directs the personal application of this moral principle in Similitude 5.7: 'Keep this flesh of yours pure and undefiled, in order that the Spirit who dwells in it may bear witness for it, that your flesh may be deemed righteous' (5.7.1).

In light of this interpretation of Similitude 5, we may tackle a few other christological and pneumatological issues that arise in Similitude 9. In 9.1.1, 
the interpreting angel of repentance tells Hermas, 'I want to show to you what the Holy Spirit who spoke with you in the form of the church showed

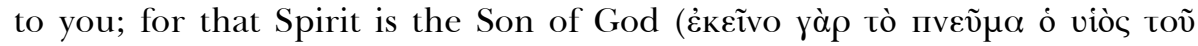
$\theta \varepsilon o \tilde{v}$ ह̇otıv).' As perplexing as it may be for modern minds, we must not lose sight of the fact that we are dealing with the fluid vocabulary and syntax of visions and parables, not with the fixed logic of scholarly treatises. On this passage, Osiek (1999: 212) writes: 'It is not correct to say that the church is therefore equated with the Son of God, any more than it is correct to say that the Son of God and the Holy Spirit are equated in Sim. 5.5... The fact that this new meaning comes only here is typical of the additive style of the author, whereby new meanings are given to old images almost as an afterthought.' The idea that the symbols contained in visions or parables would be explained with two distinct but related interpretations is not unique to Similitudes 5 and 9. In fact, in Similitude 8.3.2- the parable of the willow tree-the Shepherd set forth his interpretation this way: 'This great tree sheltering plains and hills and all the earth, is the law of God which was given to all the world; and this law is the Son of God proclaimed unto the ends of the earth.'

In Similitude 9.1.1, then, the author was not equating the Holy Spirit, the woman of the earlier visions, the Church, and the Son of God in a personal sense. Henne (1992a: 254) even suggests that in many places the phrase 'holy spirit' is to be understood in a non-technical sense, as in the vision of the twelve virgins, who are symbols of twelve 'holy spirits' of God (cf. Herm. Sim. 9.13.2-5). These are personifications of the moral effects or virtues of the Spirit, like Paul's 'fruit of the Spirit' (Galatians 5:22-23). Perhaps we are seeing something like this in the imagery of Similitude 9.1.1.

Another issue that emerges in the study of the trinitarianism of the Shepherd is whether the Son of God is presented as a created angelic being rather than as the divine creator. If 'Michael, the great and glorious angel' ( $\dot{o}$

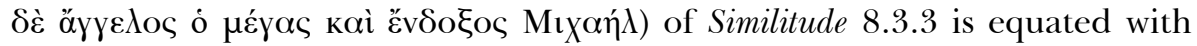
the 'Son of God', this would result in a primitive 'angel-Christology' (see Dibelius 1923: 572-576; Giet 1963: 227-228; Lebreton 1923: 658-659; McGuckin 2011: 52-53; Moxnes 1974: 49-56; Ohlig 1999: 43). However, the evidence and arguments for equating these two are weak. The description

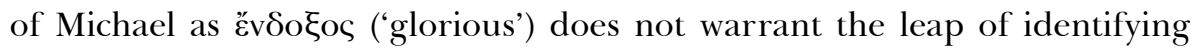

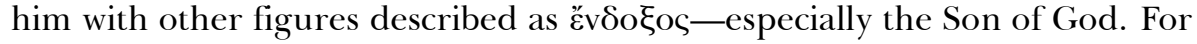
example, Gieschen (1998: 49-56) equates the 'glorious man' (the Son of God) with the 'glorious angel' (Michael).

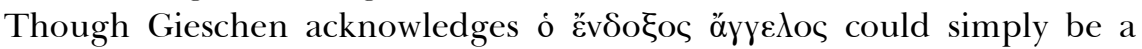
general description of the angel, he reasons, 'If this angel is distinguished from the myriads of angels due to his glory, then it is no ordinary glory, but the very Glory of the Lord. The adjective indicates that the Glorious Angel 


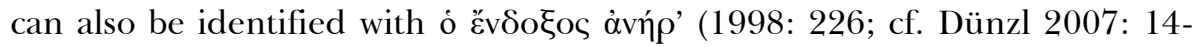

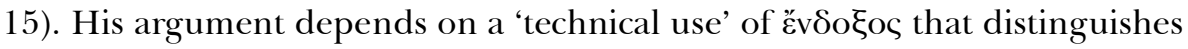
this glorious angel from others and then equates him with the glorious Son

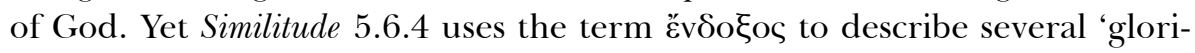

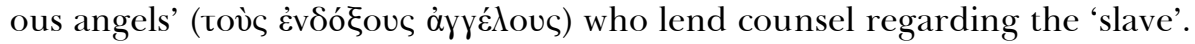

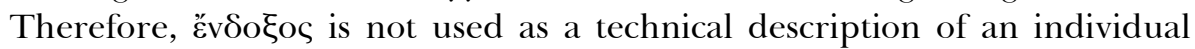
angel, Michael, but as a general description of angels. Earlier the author described these multiple glorious angels as 'the holy angels who were first

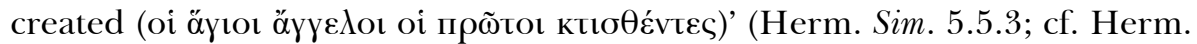

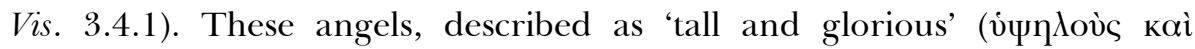

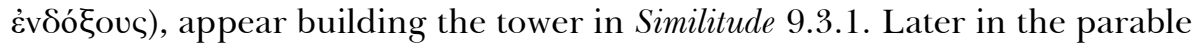
'a certain man exceedingly tall (ảví to inspect the tower. He is accompanied by the six glorious angels. 'The glo-

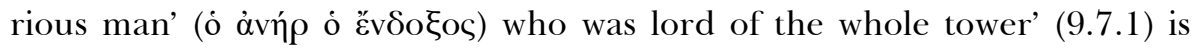
later interpreted as 'the Son of God', whereas the 'the six [men] are glorious angels surrounding him right and left'. None of these attending glorious angels can enter God's presence without the glorious Son of God (Herm. Sim. 9.12.8).

As this exposition makes clear, the phrase 'glorious man' is simply not a title or technical designation. In fact, the Shepherd himself is described as

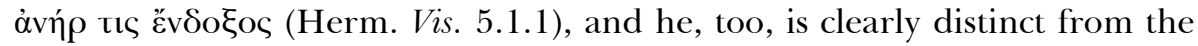
'glorious angel', Michael (see Herm. Vis. 5.1.2; Herm. Sim. 9.1.3). Therefore, equating the 'glorious angel', Michael, and the 'glorious man', the Son of God, is unwarranted. It makes more sense to regard Michael as himself one of the six 'glorious angels' who were created first and given authority to rule over the earth (cf. LXX of Daniel 10:13; Herm. Sim. 5.5.3). In short, the Shepherd never equates the Son of God with an 'angel'. We have a consistent christology in Shepherd of Hermas in which the Son is distinct from the Father and the Spirit, though all three are divine and glorious.

To summarize this analysis of the supposed 'scandalous' trinitarianism of the Shepherd of Hermas, the charges of sub-orthodox christology, confused pneumatology, and non-trinitarian theology are not sustained by the passages often cited as evidence. These passages-especially Similitudes 5 and 9 -are better read in conformity with a classic incarnational narrative of the divine Son distinct from the Spirit, both sent by the Father to accomplish the divine plan of creation, revelation, and redemption. The Shepherd of Hermas may be puzzling, peculiar, and perplexing, but it does not present an insurmountable problem for nascent trinitarianism.

\section{Conclusion}

An underlying trinitarian theology may be genuinely sketchy in the Didache, admittedly scant in the Epistle of Barnabas, and, at first blush, seemingly 
scandalous in the Shepherd of Hermas. However, a close analysis of these early non-canonical Christian works actually discloses the basic contours of an implied trinitarian creation-redemption narrative. This nascent trinitarianism may not be as explicit as in later Christian writings, nor is it afforded the increasing clarity we will see building up to the fourth century. However, not only can these three texts be responsibly read as presupposing a fundamental trinitarian theology centered on the person and work of Christ, but they also build a stable bridge from the earliest apostolic thought expressed in the New Testament to the beginnings of trinitarian theoria in the early apologists of the second century. As such, these three writings should not be considered unseemly mutations in an unsettling evolution of trinitarianism. Rather, Didache, Barnabas, and the Shepherd can be regarded as positive representatives of nascent trinitarian theology.

\section{Bibliography}

Anatolios K (2011) Retrieving Nicaea: The Development and Meaning of Trinitarian Doctrine Grand Rapids, MI: Baker Academic.

Barnard L (1958) The Problem of the Epistle of Barnabas. Church Quarterly Review 159(331): 211-230.

Barnard L (1993) The 'Epistle of Barnabas' and Its Contemporary Setting. In Haase W (ed) Aufstieg und Niedergang der Römischen Welt Part II, Principat, volume 27, part 1, Religion (Vorkonstantinische Christentum: Apostolischen Väter und Apologeten). Berlin: De Gruyter, pp. 159-207.

Beisner C (1984) God in Three Persons. Wheaton, IL: Tyndale House.

Brox N (1991) Der Hirt des Hermas (Kommentar zu den Apostolischen Vätern 7). Göttingen: Vandenhoeck \& Ruprecht.

Butin P (2001) The Trinity. Foundations of Christian Faith. Louisville, KY: Geneva.

Clark GH (1990) The Trinity. 2nd edition. Jefferson, MD: Trinity Foundation.

Coppedge A (2007) The God Who Is Triune: Revisioning the Christian Doctrine of God. Downers Grove, IL: IVP Academic.

Cullmann O (1963) The Christology of the New Testament, revised edition. London: SCM.

Dibelius M (1923) Der Hirt des Hermas (Handbuch zum Neuen Testament; Die Apostolischen Väter 4). Tübingen: Mohr.

Draper J (1996) The Jesus Tradition in the Didache. In Draper J (ed) The Didache in Modern Research (Arbeiten zur Geschichte des antiken Judentums und des Urchristentums 37). Leiden: Brill, pp. 72-91.

Draper J (2007) The Didache. In Foster P (ed) The Writings of the Apostolic Fathers. London: T \& T Clark, pp. 13-20. 
Dünzl F (2007) A Brief History of the Doctrine of the Trinity in the Early Church, Bowden J (trans). London: T \& T Clark.

Fairbairn D (2009) Life in the Trinity: An Introduction to Theology with the Help of the Church Fathers. Downers Grove, IL: IVP Academic.

Fatula M (1990) The Triune God of Christian Faith (Zacchaeus Studies: Theology). Collegeville, MN: Michael Glazier.

Fortman E (1972) The Triune God: A Historical Study of the Doctrine of the Trinity (Theological Resources). Philadelphia, PA: Westminster.

Gieschen C (1998) Angelomorphic Christology: Antecedents and Early Evidence (Arbeiten zur Geschichte des antiken Judentums und des Urchristentums 42). Leiden: Brill.

Giet S (1963) Hermas et les Pasteurs: Les trois auteurs du Pasteur d'Hermas. Paris: Presses Universitaires de France.

Giles K (2002) The Trinity and Subordinationism: The Doctrine of God and the Contemporary Gender Debate. Downers Grove, IL: IVP Academic.

Grant RM (1964) An Introduction. In Grant RM (ed) The Apostolic Fathers: A New Translation and Commentary, volume 1. New York, NY: Nelson.

Grant RM (ed) (1967) After the New Testament. Philadelphia, PA: Fortress.

Grant RM (1990) Jesus after the Gospels: The Christ of the Second Century (The Hale Memorial Lectures of Seabury-Western Theological Seminary). Louisville, KY: Westminster/John Knox.

Graydon FS (1968) The Shepherd of Hermas. In Grant RM (ed) The Apostolic Fathers: A New Translation and Commentary, volume 6. Camden, NJ: Nelson.

Gunton C (1998) The Triune Creator: A Historical and Systematic Study (Edinburgh Studies in Constructive Theology). Edinburgh: Edinburgh University Press.

Hanson AT (1989) The Activity of the Pre-existent Christ as Reflected in the Epistle of Barnabas. Studia Patristica 21(3): 155-159.

Harnack A (1905) History of Dogma, volume 1, Buchanen N (trans). London: Williams \& Norgate.

Hartog PA (2014) The Nascent 'Trinitarian' Worship of Martyrdom of Polycarp 14 and Ephesians 1. In Anatolios K (ed) The Holy Trinity in the Life of the Church. Grand Rapids, MI: Baker Academic, pp. 39-54.

Hauck RJ (1993) The Great Fast: Christology in the Shepherd of Hermas. Anglican Theological Review 75(2): 187-198.

Henne P (1988) À propos de la Christologie du Pasteur d'Hermas: la cohérence interne des niveaux d'explication dans la Cinquième Similitude. Revue des Sciences philosophiques et théologiques 72(4): 569-578.

Henne P (1992a) La christologie chez Clément de Rome et dans le Pasteur d'Hermas (Paradosis: Études de littérature et de théologie anciennes). Freiburg: Éditions Universitaires Fribourg Suisse. 
Henne P (1992b) L'unité du Pasteur d'Hermas: Tradition et redaction. Paris: Gabalda.

Hildebrand SM (2011) The Trinity in the Ante-Nicene Fathers. In Emery G and Levering $\mathrm{M}$ (eds) The Oxford Handbook of the Trinity. Oxford: Oxford University Press, pp. 95-108.

Hodgson L (1944) The Doctrine of the Trinity (Croall Lectures). New York, NY: Charles Scriber's Sons.

Holmes MW (ed) (2007) The Apostolic Fathers: Greek Texts and English Translations of Their Writings. 3rd edition. Grand Rapids, MI: Baker Academic.

Holmes S (2012) The Quest for the Trinity: The Doctrine of God in Scripture, History, and Modernity. Downers Grove, IL: IVP Academic.

Jeffers J (1990) Pluralism in Early Roman Christianity. Fides et Historia 22(1): 4-17.

Jefford C (2006) The Apostolic Fathers and the New Testament. Peabody, MA: Hendrickson.

Joly R (1993) Le milieu complexe du 'Pasteur d'Hermas'. In Haase W (ed) Aufstieg und Niedergang der Römischen Welt Part II, Principat, volume 27, part 1, Religion (Vorkonstantinische Christentum: Apostolischen Väter und Apologeten). Berlin: De Gruyter, pp. 524-551.

Kirkland A (1992) The Literary History of the Shepherd of Hermas. Second Century 9(2): 87-102.

Kraft R (1965) Barnabas and the Didache. In Grant RM (ed) The Apostolic Fathers: A New Translation and Commentary, volume 3. Camden, NJ: Nelson.

Kuruvilla A (2013) Privilege the Text! A Theological Hermeneutic for Preaching. Chicago, IL: Moody.

LaCugna CM (1991) God for Us: The Trinity and Christian Life. San Francisco, CA: HarperCollins.

Lebreton J (1923) Histoire du dogme de la Trinité des origines au Concile de Nicée, volume 2: De Saint Clément à Saint Irénée. 3rd edition [Bibliothèque de théologie historique]. Paris: Beauchesne.

Letham R (2004) The Holy Trinity: In Scripture, History, Theology, and Worship. Phillipsburg, NJ: P \& R.

Loman J (2005) The Letter of Barnabas in Early Second-Century Egypt. In Hilhorst A and van Kooten GH (eds) The Wisdom of Egypt: Jewish, Early Christian, and Gnostic Essays in Honour of Gerard P. Luttikhuizen (Ancient Judaism and Early Christianity 59). Leiden: Brill, pp. 247-265.

Longenecker RN (1970) The Christology of Early Jewish Christianity. Grand Rapids, MI: Baker.

Longenecker RN (1999) Biblical Exegesis in the Apostolic Period. 2nd edition. Grand Rapids, MI: Eerdmans.

de Margerie B (1975) La Trinité Chrétienne dans L'histoire (Théologie Historique 31). Paris: Beauchesne. 
Marmion D and van Mieuwenhove R (2011) An Introduction to the Trinity. Cambridge: Cambridge University Press.

Mascall EL (1986) The Triune God: An Ecumenical Study. Allison Park, PA: Pickwick.

McGuckin JA (2011) The Trinity in the Greek Fathers. In Phan P (ed) The Cambridge Companion to the Trinity. Cambridge: Cambridge University Press, pp. 49-69.

Moxnes H (1974) God and His Angel in the Shepherd of Hermas. Studia Theologica 28(1): 49-56.

Niederwimmer K (1998) The Didache: A Commentary (Hermeneia). Minneapolis, MA: Fortress.

O'Collins G (1999) The Tripersonal God: Understanding and Interpreting the Trinity. New York, NY: Paulist.

O’Hagen AP (1963). Early Christian Exegesis Exemplified from the Epistle of Barnabas. Australian Biblical Review 11(1): 39-40.

Ohlig K-H (1999) Ein Gott in drei Personen? Vom Vater Jesu zum 'Mysterium' der Trinität. Mainz: Matthias-Grünewald-Verlag.

Olson R. and Hall C (2002) The Trinity (Guides to Theology). Grand Rapids, MI: Eerdmans.

Osiek C (1999) The Shepherd of Hermas: A Commentary (Hermeneia). Minneapolis, MN: Fortress.

Paget JC (1994) The Epistle of Barnabas: Outlook and Background (Wissenschaftliche Untersuchungen zum Neuen Testament n. s. 64). Tübingen: Mohr Siebeck.

Paine L (1900) A Critical History of the Evolution of Trinitarianism and Its Outcome in the New Christology. Boston, MA: Houghton, Mifflin and Company.

Panadrea J (2016) The Earliest Christologies: Five Images of Christ in the Postapostolic Age Downers Grove, IL: IVP Academic.

Pannenberg W (1991) Systematic Theology, volume 1, Bromiley GW (trans). Grand Rapids, MI: Eerdmans.

Pittenger N (1977) The Divine Trinity. Philadelphia, PA: United Church Press.

Prigent P (1961) Les Testimonia dans le christianisme primitif: L'épître de Barnabé I-XVI et ses sources (Études bibliques). Paris: Gabalda.

Prostmeier F-R (1999) Der Barnabasbrief (Kommentar zu den Apostolischen Vätern 8). Göttingen: Vandenhoeck \& Ruprecht.

Stewart-Sykes A (1997) The Christology of Hermas and the Interpretation of the Fifth Similitude. Augustinianum Rome 37(2): 273-284.

Svigel MJ (2016) The Center and the Source: Second Century Incarnational Christology and Early Catholic Christianity (Gorgias Studies in Early Christianity and Patristics 66). Piscataway, NJ: Gorgias. 
Verheyden J (2007) The Shepherd of Hermas. In Foster P (ed) The Writings of the Apostolic Fathers. London: T \& T Clark, pp. 63-71.

Vermes G (2014) Christian Beginnings: From Nazareth to Nicaea. New Haven, CT: Yale University Press.

Wengst K (1984) Didache (Apostellehre), Barnabasbrief, Zweiter Klemensbrief, Schrift an Diognet: Eingeleitet, herausgegeben, übertragen und erläutert (Schrift des Urchristentums 2). Munich: Kösel.

Wilson J (1995) Five Problems in the Interpretation of the Shepherd of Hermas: Authorship, Genre, Canonicity, Apocalyptic, and the Absence of the Name 'Jesus Christ' (Biblical Series 34). Lewiston, NY: Mellen.

Witherington B (1998) The Many Faces of the Christ: The Christologies of the New Testament and Beyond (Companions to the New Testament). New York, NY: Crossroad. 